\title{
Marigold and Pepper Growth in Container Substrates Made from Biosolids Composted with Carbon-rich Organic Wastes
}

\author{
Rita L. Hummel ${ }^{1}$, Craig Cogger, Andy Bary, and Robert Riley
}

ADDITIONAL INDEX WORDs. aerobic static pile, anaerobic digestion, Capsicum annuиm, digester fiber, nitrogen fertilization, peat substitute, small-scale composting, Tagetes patula

Summary. Composts made from organic wastes have the potential to substitute for peat and bark as components of container growth substrates. Composts for this research were produced in small-scale aerobic bins using biosolids blended with construction debris, storm debris, or horse waste in a $1: 3$ (v:v ratio). The composts were screened and blended 1:1 (v:v) with douglas fir (Pseudotsuga menziesii) bark to produce substrates. They were compared with a peat-perlite control substrate, a biosolids blend control substrate, and substrates made from a commercial biosolids compost mixed 1:1 with bark and from fiber from an anaerobic digester (dairy manure and food waste) mixed 1:1 with bark. Chemical and physical properties of the substrates were measured before transplanting, and growth, quality, and leaf color of 'Little Hero Flame' marigold (Tagetes patula) and 'Golden California Wonder' bell pepper (Capsicum annuum) were measured in a replicated greenhouse study comparing the substrates at two rates of nitrogen $(\mathrm{N})$ application. The experimental biosolids composts-bark substrates performed similar to the peat-perlite and biosolids blend controls for growing marigold and pepper. The commercial biosolids compost mixed with bark did not perform as well as the experimental substrates or the controls. Digester fiber-bark was intermediate between commercial biosolids compost-bark and other treatments. Higher $\mathbf{N}$ rates improved plant growth and quality across all container substrates in pepper, but had fewer significant effects on marigold. Experimental substrates were coarser texture than the peat-perlite or biosolids blend controls, resulting in higher aeration porosity (AP) and lower water-holding capacity (WHC), but performed well nonetheless under the drip irrigation used in this study. Using locally sourced organic waste materials as container substrates can help capture value from organic wastes and contribute to the sustainability of nursery production practices.

$\mathrm{C}$ omposted organic wastes have the potential to substitute for peat and bark as components of the growth substrates in containerized plant production systems (Carlile, 2008; Clark and Cavigelli, 2005; Estévez-Schwarz et al., 2009; Fitzpatrick, 2001; Gouin, 1995; Moore, 2005; Raviv, 2005; Sterrett, 2001). Most of the feedstocks used for composting are readily available

Washington State University Puyallup Research and Extension Center 2606 West Pioneer, Puyallup, WA 98371

The Washington State Department of Ecology provided partial funding for this project through the Beyond Waste Organics Waste to Resources (OWR) project. These funds were provided in the 2007-09 Washington State budget from the Waste Reduction Recycling and Litter Control Account. OWR project goals and objectives were developed by the Beyond Waste Organics team, and were approved by the Solid Waste and Financial Assistance Program. Partial funding also came from USDA/NIFA through Hatch projects WNP3755 and WNP0722

We thank Susan Smith and Liz Myhre for their technical assistance.

${ }^{1}$ Corresponding author. E-mail: hummelrl@wsu.edu. from local sources. Sourcing locally available feedstocks for conversion to container substrates eliminates the need for long-distance transport thereby reducing both the environmental and economic costs of the substrates. The container plant industry is an obvious choice for using some of these recycled wastes because of its constant need for plant growth substrates. As plants are sold, the containers and the media inside are sold with them, resulting in the demand for more.

Growers must have a reliable source of high-quality growth substrates that are consistent over time. From a grower's perspective, one of the major impediments to using composts for container substrates is the variation in physical and chemical characteristics between different types of compost, different sources of compost, and even between different batches of the same compost from the same source (Bettineski, 1996; Fitzpatrick, 2001; Sterrett, 2001; Tyler, 1996). Compost producers must manufacture their products to meet the needs of container growers (Moore, 2005; Raviv, 1998; Sterrett, 2001).

Previous research at Washington State University, Puyallup, has shown that a blend of Tagro mix, produced by the City of Tacoma, WA, and bark is equal to or superior than standard peat-based substrates for growing chrysanthemum (Chrysanthemum $\times$ morifolium) in greenhouse (Krucker et al., 2010). Tagro mix is a garden amendment made from Class A biosolids from the City of Tacoma $(50 \%)$, screened sand $(25 \%)$, and sawdust (25\%). Biosolids are a residual product of wastewater treatment (sewage sludge) that has been treated to meet U.S. Environmental Protection Agency (USEPA) quality standards for land application (Sullivan et al., 2007). Class A biosolids undergo an enhanced pathogen removal step to make them suitable for home and garden use. Biosolids from a given source tend to have a more consistent composition than other recycled organic materials, which is an advantage for container substrate production. The City of Tacoma now produces Tagro Potting Soil from Tagro Mix and bark and sells it locally as the most profitable

\begin{tabular}{llll}
\hline $\begin{array}{l}\text { Units } \\
\begin{array}{l}\text { To convert U.S. to SI, } \\
\text { multiply by }\end{array}\end{array}$ & U.S. unit & SI unit & $\begin{array}{l}\text { To convert SI to U.S., } \\
\text { multiply by }\end{array}$ \\
\hline 29.5735 & $\mathrm{fl} \mathrm{oz}$ & $\mathrm{mL}$ & 0.0338 \\
2.54 & inch $(\mathrm{es})$ & $\mathrm{cm}$ & 0.3937 \\
25.4 & inch $(\mathrm{es})$ & $\mathrm{mm}$ & 0.0394 \\
0.5933 & $\mathrm{lb} / \mathrm{yard}$ & $\mathrm{kg} \cdot \mathrm{m}^{-3}$ & 1.6856 \\
1 & $\mathrm{mmho} / \mathrm{cm}$ & $\mathrm{dS} \cdot \mathrm{m}^{-1}$ & 1 \\
28.3495 & $\mathrm{oz}$ & $\mathrm{g}$ & 0.0353 \\
1 & $\mathrm{ppm}$ & $\mathrm{mg} \cdot \mathrm{L}^{-1}$ & 1 \\
0.9464 & $\mathrm{qt}$ & $\mathrm{L}$ & 1.0567 \\
0.7646 & $\mathrm{yard}$ & $\mathrm{m}$ & 1.3080 \\
$\left({ }^{\circ} \mathrm{F}-32\right) \div 1.8$ & ${ }^{\circ} \mathrm{F}$ & ${ }^{\circ} \mathrm{C}$ & $\left({ }^{\circ} \mathrm{C} \times 1.8\right)+32$ \\
& & &
\end{tabular}


product of their biosolids stream (City of Tacoma, 2011). It has become accepted by users as a quality potting substrate and garden amendment. The city produces about 4000 yard $^{3}$ of Tagro Potting Soil annually, using $25 \%$ of their biosolids stream.

Biosolids composts have the potential to be a major ingredient in locally produced container substrates (Bugbee, 2002; Fitzpatrick, 2001; Klock-Moore, 1999; Krucker et al., 2010; Sterrett, 2001). Class B biosolids are suitable for farm or forestry use, but they must go through another pathogen reduction step (such as composting) to become a Class A material suitable for use in gardens, parks, and greenhouses. Carbon-rich recyclable materials such as woody construction debris, woody storm debris, and horse manure are abundant around metropolitan areas (Frear et al., 2005), and these could be composted with Class B biosolids to make a Class A product that could potentially be used in container substrates.

Use of locally available organic waste materials and biosolids as substrates would enhance the sustainability of container plant production systems. Results of a consumer preference survey for ornamentals, vegetable transplants, and herbs indicated consumers were interested in obtaining plants produced locally and sustainably (Yue et al., 2011). The objective of this research was to determine the suitability of composts made with biosolids and different locally produced urban organic carbon sources for use as container substrates, based on physical and chemical properties and plant growth response at two nitrogen rates under greenhouse conditions.

\section{Materials and methods}

Seeds of 'Little Hero Flame' marigold and 'Golden California Wonder' pepper were sown in plug trays ( 96 cell size, $32-\mathrm{mL}$ volume) in peat-perlite plug mix (Sunshine Mix \#25; Sun Gro Horticulture, Bellevue, WA) on 6 Feb. 2009. At the one to two-true-leaf stage, uniform seedlings were transplanted into 0.74 -qt square containers 4 inches tall and 4 inches wide filled with the following growth substrates: 1) storm debris + biosolids compost mixed 1:1 (by volume) with douglas fir bark (bark); 2) construction debris + biosolids compost mixed 1:1 with bark; 3) horse waste + biosolids compost mixed $1: 1$ with bark; 4) Dairy manurefood waste anaerobic digester solids mixed l:1 with bark; 5) commercial biosolids-sawdust compost mixed 1:1 with bark; 6) commercially formulated bagged peat-perlite mix; 7) commercially formulated biosolids blend potting soil.

We made the compost components of the first three experimental substrates from locally available, waste-derived, carbon (C)-rich feedstocks and biosolids. The C-rich feedstocks included woody debris from wind or ice storm cleanup, woody construction debris, and horse manure mixed with straw and sawdust bedding. The storm debris and construction debris were ground using a grinder (Contender; Universal Refiner Corp., Montesano, WA) and screened to 1 inch. The biosolids were dewatered material from the South wastewater treatment plant operated by King County, WA. The biosolids met the most stringent USEPA limits for trace element concentrations and Class B pathogen requirements (USEPA, 1994). Each C-rich feedstock was combined with the biosolids in a $3: 1$ volume ratio on 15 May 2008. The mixed feedstocks were run through a manure spreader twice to blend them thoroughly, and then loaded into experimental scale aerobic reactors for composting.

The reactors consisted of 2.2$\operatorname{yard}^{3}$ bins $(48 \times 48 \times 47$ inches $)$ operated as static piles under positive aeration. The aeration system consisted of two perforated 4 -inch pipes at the bottom of the composting bin connected to a $280-\mathrm{W}$ blower via a manifold (Fig. 1). An 8-inch layer of coarse woody material was placed around the aeration pipes to serve as a plenum to improve air flow into the pile. The bins were capped with a layer of finished compost (made from yard debris and animal manures), and composted under forced aeration for 7 weeks, on an aeration cycle of $20 \mathrm{~s}$ per hour. Temperatures were measured at three depths in each pile five times per week for 4 weeks, and weekly for the next 3 weeks. Temperatures met USEPA standards for pathogen reduction to achieve Class $\mathrm{A}\left(131^{\circ} \mathrm{F}\right.$ or greater for at least $\left.3 \mathrm{~d}\right)$ in the upper two depths of each pile, but not at the lowest depth, which was located in the plenum. The bins were emptied and the composts cured in freestanding piles for an additional 15 weeks (until 17 Oct.). A portion of the cured compost was sieved (7/16 inch) and saved for the preparation of the potting substrates. Carbon to nitrogen $(\mathrm{C}: \mathrm{N})$ ratios of the finished composts were 16:1 for the storm debris-biosolids and construction debris-biosolids composts, and 14:1 for the horse waste-biosolids compost. Total $\mathrm{C}$ and total $\mathrm{N}$ were determined on samples sent to the University of Nebraska analytical laboratory, using a combustion analyzer equipped with IR detector (LECO Instruments, St. Joseph, MI).

Dairy manure-food waste anaerobic digester solids were produced in a commercial digester located on a local dairy farm. The digester operated at $23.5^{\circ} \mathrm{C}$ and had a $17-\mathrm{d}$ retention time. The solids were separated from the digestate using a rotating drum screen separator. Digester solids C:N ratio was 12:1. Commercial biosolids compost was obtained from the producer (Groco; Sawdust Supply Co., Seattle, WA). It is made from fir/ hemlock sawdust and anaerobically digested King County Class B biosolids, blended in a 3 to 1 ratio. The feedstocks are composted in windrows for $30 \mathrm{~d}$, and then cured in a large pile for at least 1 year. The Commercial biosolids compost had a C:N ratio of 29:1. The four composts and the anaerobic digester solids were mixed 1:1 (by volume) with $100 \%$ fine-ground fresh douglas fir bark before use as container substrates. Previous research (Krucker et al., 2010) showed that mixing compost and biosolids products with bark improved their performance as container substrates. Particle size distribution of douglas fir bark and the seven growth substrates was determined by shaking samples $(\approx 500 \mathrm{~g})$ on a sieve shaker through U.S. Standard Tyler screens (Table 1).

The commercially formulated biosolids blend potting soil was obtained from the manufacturer (Tagro Potting Soil; Central Wastewater Treatment Plant, Tacoma, WA). It consists of $20 \%$ Tacoma thermophilically digested Class A biosolids by volume, 20\% maple (Acer sp.) sawdust, and $60 \%$ clean, aged bark. Tacoma biosolids meet Class A pathogen reduction requirements without further 


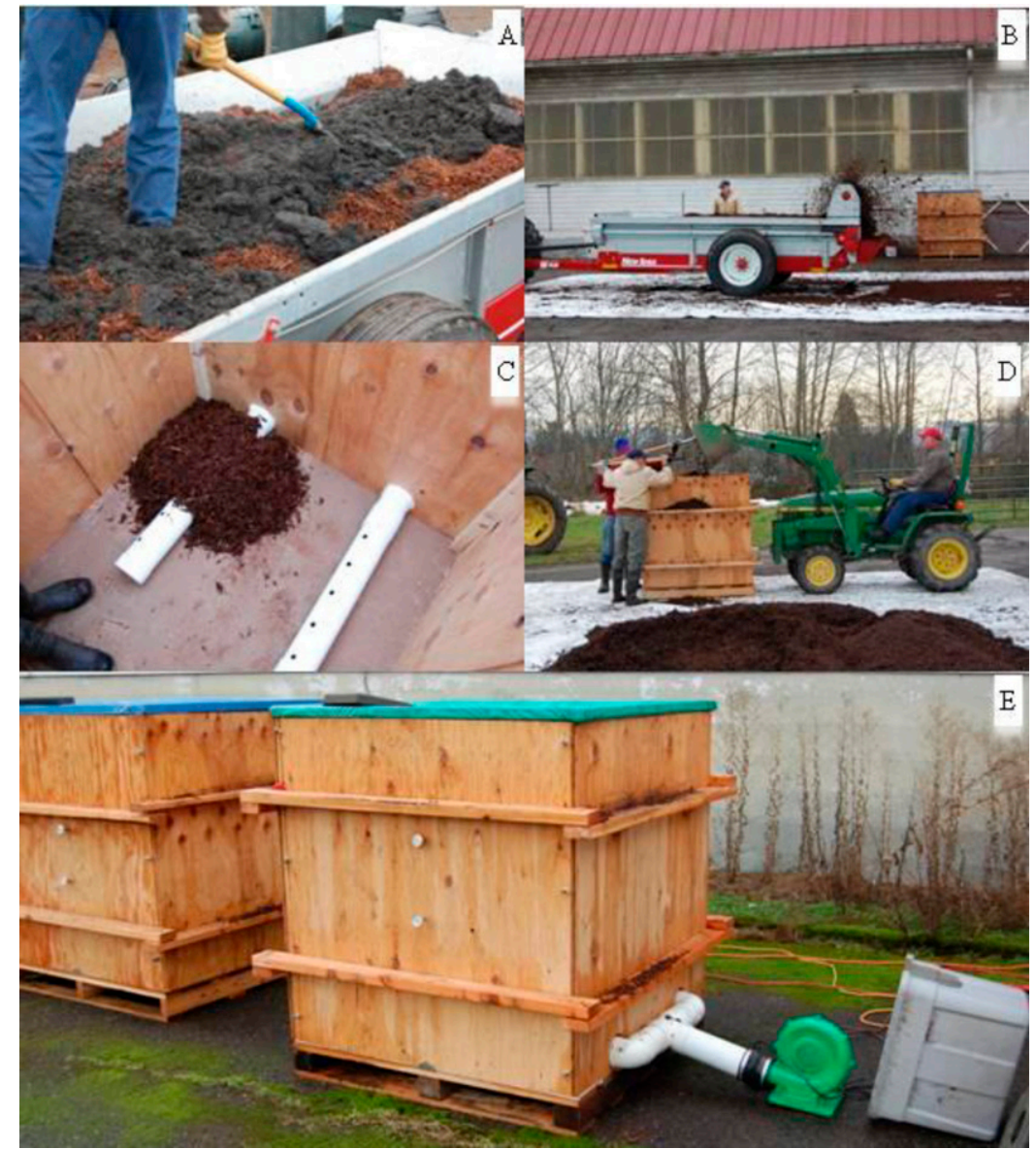

Fig. 1. Compost production in small-scale aerobic bins (A) biosolids layered with waste-derived, carbon-rich feedstock in a manure spreader and (B) mixed by spreading on a large tarp. Aeration system (C) at bottom of 2.2 -yard ${ }^{3}\left(1.68-\mathrm{m}^{3}\right)$ composting bin partially covered with plenum material. Bins were loaded (D), connected to a blower (E) and maintained under forced aeration for 7 weeks. Temperature was monitored via thermometers inserted through pre-drilled holes in the bin wall. One side of the bin is removable for ease of emptying.

treatment, and the biosolids blend was a blend, not a compost. The commercially formulated bagged peatperlite mix was $70 \%$ to $80 \%$ sphagnum peatmoss, perlite, and only dolomitic limestone and gypsum with no other nutrients added (Sunshine Mix \#2, Sun Gro Horticulture). The peatperlite and biosolids blend substrates were used as control treatments.

Before transplanting, all substrates were amended with micronutrient mix (Micromax; Scotts, Marysville, $\mathrm{OH}$ ) at the rate of 1.75 $\mathrm{lb} /$ yard $^{3}$, and all except the commercially formulated peat-perlite substrate were amended with dolomite at the rate of $8 \mathrm{lb} /$ yard $^{3}$. Finally, tests were conducted on triplicate samples of the substrates to measure initial pH (model EN 50081-1 pH meter; Hanna Instruments, Woonsocket, $\mathrm{RI})$, electrical conductivity [EC (model 128 EC meter; Orion Research, Beverly, MA)], WHC, AP, and nitrate $\left(\mathrm{NO}_{3}\right)-\mathrm{N}$ levels (model $44700 \mathrm{pH} / \mathrm{ISE}$ meter with nitrate electrode; Hach, Loveland, CO) (Table 2). Substrate $\mathrm{pH}, \mathrm{EC}$, and $\mathrm{NO}_{3}-\mathrm{N}$ were determined using the 1:5 method (Thompson et al., 2001). Water-holding capacity and AP were determined by following the volume displacement measurement technique described by Ingram et al. (1990).

Immediately after transplant, marigold and pepper plants were manually watered to thoroughly leach the substrates. Pots for each species were randomized and placed on greenhouse benches under a drip irrigation system. Water was applied through an emitter consisting of a 10 -inch length of $1 / 8$-inch microtubing with holes laser drilled in a preset spacing of 2.5 inches that was formed into a 3.2-inch-diameter circle around the stem of each plant. The circular emitter was attached via a Tee-fitting to a nonperforated $1 /$ 8 -inch microtube that was attached to a pressure compensating drip emitter originating on the $5 / 8$-inch irrigation main line. This arrangement allowed for uniform distribution of water to the surface of the growth substrate. Plants were inspected and pot weights judged for signs of water depletion. Plants were typically irrigated daily to produce a leaching fraction (volume of leachate/volume of water applied) of 0.1 to 0.2 . Plant growth and weather conditions were monitored, and as plants grew a second daily irrigation was added.

The experiment included two $\mathrm{N}$ treatments. For the high $\mathrm{N}$ treatment, plants were fertilized with a 200 $\mathrm{mg} \cdot \mathrm{L}^{-1} \mathrm{~N}, 43.7 \mathrm{mg} \cdot \mathrm{L}^{-1}$ phosphorus $(\mathrm{P})$, and $166 \mathrm{mg} \cdot \mathrm{L}^{-1}$ potassium $(\mathrm{K})$ solution applied every other day. For the low $\mathrm{N}$ rate treatment, the plants were fertilized with the same solution every $4 \mathrm{~d}$. To ensure uniformity of $\mathrm{P}$ and $\mathrm{K}$ application, the low $\mathrm{N}$ plants were fertilized with a solution containing $43.7 \mathrm{mg} \cdot \mathrm{L}^{-1} \quad \mathrm{P}$ and 166 $\mathrm{mg} \cdot \mathrm{L}^{-1} \mathrm{~K}$ but without $\mathrm{N}$ on the intervening fertilization days. Thus, all plants received the same amount of $\mathrm{P}$ and $\mathrm{K}$ applied every other day; only the $\mathrm{N}$ rate varied. Fertilizer solutions were prepared with combinations of ammonium nitrate (EM Science, Darmstadt, Germany), potassium sulfate (J.T. Baker Chemical, Phillipsburg, NJ), and potassium phosphate monobasic (EM Science). Plants were fertilized by hand application of $60 \mathrm{~mL}$ of solution to the surface of the substrate. No additional irrigation was applied on the days plants were fertilized. Greenhouse temperatures were set at $70 / 62{ }^{\circ} \mathrm{F}$ (day/night). Irrigation water $\mathrm{pH}$ was 7.0 and $\mathrm{EC}$ was $0.2 \mathrm{dS} \cdot \mathrm{m}^{-1}$. High-pressure sodium lights provided $254 \mu \mathrm{mol} \cdot \mathrm{m}^{-2} \cdot \mathrm{s}^{-1}$ at plant height (LI-190 Quantum Sensor; LI-COR, Lincoln, NE) for a 15-h daily photoperiod.

Initial plant height and the narrowest and widest canopy widths were recorded at transplanting. At the end of production, 7 and 11 weeks from seeding for marigold and pepper, respectively, when the first flower was fully open, stem height and the widest and narrowest canopy width were again measured. 
Table 1. Particle size distribution of dried douglas fir bark and the dried experimental growth substrates. Construction debris-biosolids, horse waste-biosolids, and storm debris-biosolids composts were made in small-scale aerobic reactors and prescreened to pass a $7 / 16$-inch $(11.1 \mathrm{~mm})$ sieve before mixing with bark. Digester solids and commercial biosolids compost were obtained from local manufacturers. Bark indicates substrates were amended with douglas fir bark at a $1: 1$ (v:v) ratio. Peat-perlite and biosolids blend are commercially available growth substrates and were used as controls.

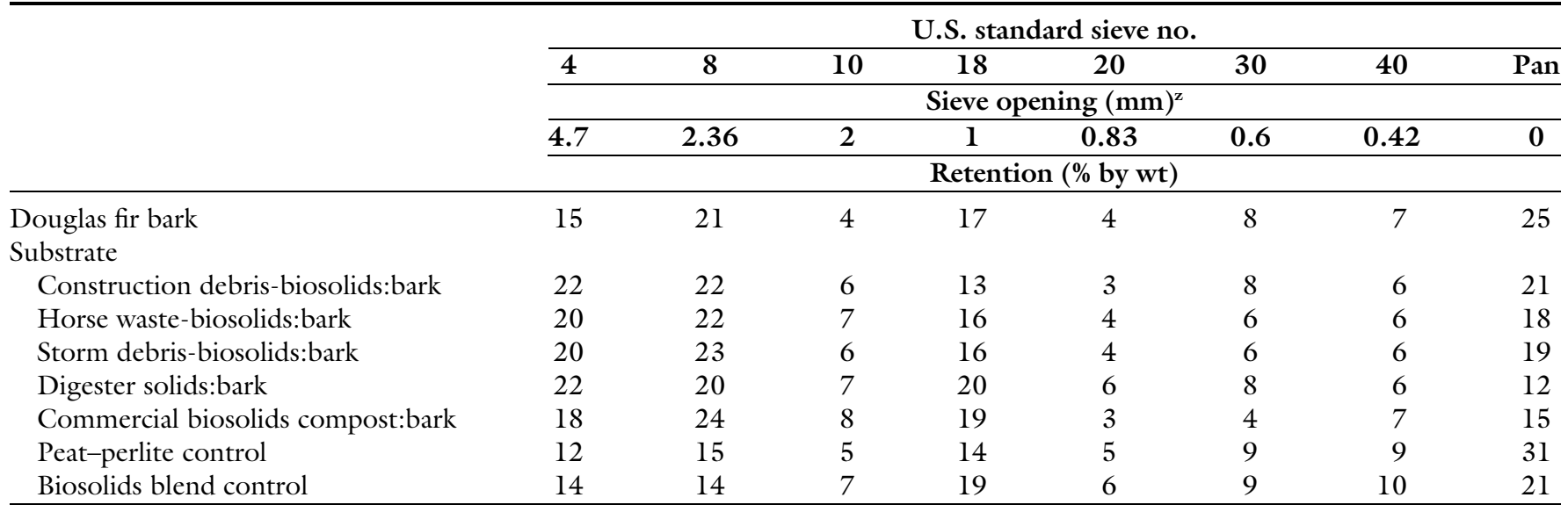

${ }^{2} 1 \mathrm{~mm}=0.0394$ inch.

Table 2. Initial aeration porosity (AP), water-holding capacity (WHC), $\mathrm{pH}$, electrical conductivity (EC), and nitratenitrogen $\left(\mathrm{NO}_{3}-\mathrm{N}\right)$ levels of the container growth substrates. Construction debris-biosolids, horse waste-biosolids, and storm debris-biosolids composts were made in small-scale aerobic reactors and the digester solids and commercial biosolids compost were obtained from local manufacturers. Bark indicates substrates were amended with douglas fir bark at a 1:1 (v:v) ratio. Peat-perlite and biosolids blend are commercially available growth substrates and were used as controls. ${ }^{\mathrm{z}}$

\begin{tabular}{|c|c|c|c|c|c|}
\hline Substrate & $\mathrm{AP}(\%)$ & WHC (\%) & $\mathrm{pH}$ & $\mathrm{EC}\left(\mathrm{dS} \cdot \mathrm{m}^{-1}\right)^{\mathrm{y}}$ & $\mathrm{NO}_{3}-\mathrm{N}\left(\mathrm{mg} \cdot \mathrm{L}^{-1}\right)^{y}$ \\
\hline Construction debris-biosolids:bark & $22 a^{x}$ & $30 \mathrm{~cd}$ & $5.8 \mathrm{~b}$ & $1.4 \mathrm{~b}$ & $77 \mathrm{~b}$ \\
\hline Horse waste-biosolids:bark & $21 \mathrm{a}$ & $32 \mathrm{bc}$ & $5.9 \mathrm{~b}$ & $1.6 \mathrm{a}$ & $87 \mathrm{a}$ \\
\hline Storm debris-biosolids:bark & $23 a$ & $28 \mathrm{~d}$ & $5.7 \mathrm{bc}$ & $1.4 \mathrm{~b}$ & $79 \mathrm{ab}$ \\
\hline Digester solids:bark & $17 \mathrm{bc}$ & $32 \mathrm{bc}$ & $6.8 \mathrm{a}$ & $1.0 \mathrm{c}$ & $21 \mathrm{~d}$ \\
\hline Commercial biosolids compost:bark & $18 \mathrm{~b}$ & $32 \mathrm{bc}$ & $5.8 \mathrm{~b}$ & $0.5 \mathrm{~d}$ & $17 \mathrm{~d}$ \\
\hline Peat-perlite control & $15 \mathrm{c}$ & $42 \mathrm{a}$ & $5.5 \mathrm{c}$ & $0.9 \mathrm{c}$ & 3 e \\
\hline
\end{tabular}

${ }^{2}$ The 1:5 method was used to determine $\mathrm{pH}, \mathrm{EC}$, and $\mathrm{NO}_{3}$ levels.

${ }^{y} \mathrm{l} \mathrm{dS} \cdot \mathrm{m}^{-1}=1 \mathrm{mmho} / \mathrm{cm}, 1 \mathrm{mg} \cdot \mathrm{L}^{-1}=1 \mathrm{ppm}$.

${ }^{x}$ Means within a column followed by the same letter are not significantly different at the $5 \%$ level using a protected Tukey's Studentized range test.

From this data a shoot growth index (SGI) was calculated as follows: $\{[$ (widest width + narrowest width $) \div$ $2]+$ height $\} \div 2$. Next, the final number of flowers and visible flower buds were counted, and color of the adaxial leaf surface of two fully expanded leaves from the stem midsection was determined quantitatively with a CR-400/410 Chroma Meter (Konica Minolta Sensing Americas, Ramsay, NJ). The CIELAB coordinates, $L^{*} a^{*} b^{*}$, were measured and the chroma $\left(\mathrm{C}^{*}\right)$ and hue angle $\left(\mathrm{h}^{\circ}\right)$ calculated (McGuire 1992).

After leaf color was measured, shoot visual quality of all plants was rated on a scale ranging from 5, a superior plant, to 1 , a poor quality plant with a rating of 3 considered salable. Root growth was also rated as root length and root density. Root length was rated from 4 , roots circling the bottom of the container, to 1 , roots growing $1 / 2$ way to the container bottom. Root density was rated on a 4 (solid root mass with little or no growth substrate visible at the periphery) to 1 (no roots visible at the periphery) scale. Finally, plants were cut at the substrate surface and the shoots dried for $96 \mathrm{~h}$ at $60^{\circ} \mathrm{C}$ in a forced air oven and weighed to determine shoot dry weight.

Statistical analysis. For each species, a factorial treatment combination of seven growth substrates by two $\mathrm{N}$ fertilizer rates was analyzed. There were eight replicate containers per treatment with one plant per container. Plants were arranged on greenhouse benches in a randomized complete block design. Plant data were subject to two-way analysis of variance [ANOVA (PROC GLM,
SAS version 8.1; SAS Institute, Cary, NC)]. Significant two-factor interactions necessitated the use of one-way ANOVA to test the significance of container substrate and fertilizer treatments. Mean separations for substrate were done with a protected Tukey's Studentized range test (HSD). A Student's $t$ test $(P \leq 0.05)$ was used to compare the high $\mathrm{N}$ to low $\mathrm{N}$ fertilizer treatments.

\section{Results and discussion Container substrate properties}

Initial AP (Table 2) of all but the three substrates made with bark and composts from our small-scale aerobic reactor was within the $10 \%$ to $20 \%$ range recommended for most greenhouse crops (Ingram et al., 1990). The construction debris-biosolids, horse waste-biosolids, and storm debris-biosolids substrates had slightly 
higher $\mathrm{AP}$ at $22 \%, 21 \%$, and $23 \%$, respectively. Only the peat-perlite control substrate had a WHC that fell within the $40 \%$ to $50 \%$ range recommended by Ingram et al. (1990) for most greenhouse crops. The other substrates had lower WHCs, with storm debris-biosolids having the lowest WHC at $28 \%$. The higher WHC and lower AP of peat-perlite was most likely related to its particle size distribution (Table 1) with generally fewer coarse particles $(>2 \mathrm{~mm})$ and more fine particles $(<0.5 \mathrm{~mm})$ than the other substrates. Particle size was similar among the experimental substrates with more coarse particles and fewer fines compared with the peat-perlite control. The biosolids blend control typically had fewer fines than peat-perlite, while the commercial biosolids compost and digester solids substrates had the fewest fines. The coarseness of the experimental container substrates was reflected in their higher AP and lower WHC compared with the peat-perlite or biosolids blend controls (Jackson et al., 2010).
The $\mathrm{pH}$ of all but digester solids substrates fell within the range of 5.4 to 6.6 recommended by Nelson (2012) for typical greenhouse crop soilless substrates (Table 2). Digester solids substrate had a somewhat higher than recommended initial $\mathrm{pH}$ of 6.8. The higher $\mathrm{pH}$ can be attributed to the dairy manure fiber component of the digester solids. Krucker et al. (2010) found that the $\mathrm{pH}$ of anaerobically digested dairy fiber was 7.7 , but when mixed with $50 \%$ douglas fir bark (by volume), the $\mathrm{pH}$ decreased to 6.9. Li et al. (2009) reported a $\mathrm{pH}$ of 6.9 for a commercially available dairy manure compost. Initial electrical conductivities (Table 2 ) of all but the commercial biosolids compost substrate were above the desirable range of 0.35 to $0.65 \mathrm{dS} \cdot \mathrm{m}^{-1}$ for the 1:5 method according to Warncke and Krauskopf(1983). They indicated an EC above $1.1 \mathrm{dS} \cdot \mathrm{m}^{-1} \mathrm{can}$ cause severe salt injury. Although ECs of the three experimental substrates made with biosolids and recycled urban wastes ranged from 1.4 to 1.6, no salt injury was observed on plants in any of the substrates used in this experiment. This may have been due to the thorough leach-watering plants received immediately after transplant. Nitrate- $\mathrm{N}$ levels were similar to EC with the highest $\mathrm{NO}_{3}-\mathrm{N}$ measured in the horse waste-biosolids, storm debris-biosolids, and construction debris-biosolids substrates (Table 2 ). The other substrates had lower $\mathrm{NO}_{3}-\mathrm{N}$ levels and the peat-perlite control had the lowest $\mathrm{NO}_{3}-\mathrm{N}$ level. This result was expected because the peat-perlite substrate chosen for this experiment lacked a starter or preplant fertilizer.

\section{Plant growth, quality, and number of flower buds}

Nitrogen Rates. Within a growth substrate treatment, doubling the amount of $\mathrm{N}$ by applying every second day instead of every fourth day had few significant effects on the growth of marigold plants (Table 3 ). Only SGI of marigold in the digester solids and commercial biosolids compost substrates and dry weight of horse waste-biosolids marigold were

Table 3. Effect of growth substrates and nitrogen $(\mathrm{N})$ rates on shoot growth index, dry weight, visual quality, flower and flower bud number of 'Little Hero Flame' marigold and 'Golden California Wonder' pepper. Construction debris-biosolids, horse waste-biosolids, and storm debris-biosolids composts were made in small-scale aerobic reactors and the digester solids and commercial biosolids compost were obtained from local manufacturers. Bark indicates substrates were amended with douglas fir bark at a 1:1 (v:v) ratio. Peat-perlite and biosolids blend are commercially available growth substrates and were used as controls.

\begin{tabular}{|c|c|c|c|c|c|c|c|c|c|c|c|c|}
\hline \multirow[b]{2}{*}{ Substrates } & \multicolumn{3}{|c|}{$\begin{array}{l}\text { Shoot growth } \\
\text { index }(\mathrm{cm})^{\mathrm{z}}\end{array}$} & \multicolumn{3}{|c|}{$\begin{array}{l}\text { Dry wt } \\
\qquad(g)^{y}\end{array}$} & \multicolumn{3}{|c|}{$\begin{array}{c}\text { Plant visual } \\
\text { quality }(1 \text { to } 5 \text { scale })^{x}\end{array}$} & \multicolumn{3}{|c|}{$\begin{array}{l}\text { Flowers and } \\
\text { buds (no.) }\end{array}$} \\
\hline & High Nw $^{w}$ & Low Nw & & High N & Low $\mathbf{N}$ & & High $\mathbf{N}$ & Low $\mathbf{N}$ & & High N & Low $\mathrm{N}$ & \\
\hline & & & & Marigold & & & & & & & & \\
\hline Construction debris-biosolids:bark & $15.4 \mathrm{a}^{\mathrm{v}}$ & $13.9 \mathrm{ab}$ & $\mathrm{NS}^{\mathrm{u}}$ & $3.7 \mathrm{~b}$ & $3.5 \mathrm{abc}$ & NS & $4.4 \mathrm{a}$ & $4.1 \mathrm{ab}$ & NS & $11 \mathrm{a}$ & $10 \mathrm{c}$ & NS \\
\hline Horse waste-biosolids:bark & $14.7 \mathrm{ab}$ & $14.0 \mathrm{ab}$ & NS & $4.7 \mathrm{a}$ & $3.9 \mathrm{a}$ & $* * *$ & $4.9 \mathrm{a}$ & $4.5 \mathrm{a}$ & NS & $12 \mathrm{a}$ & $13 \mathrm{a}$ & NS \\
\hline Storm debris-biosolids:bark & $13.8 \mathrm{~b}$ & $14.4 \mathrm{a}$ & NS & $3.9 \mathrm{ab}$ & $3.7 \mathrm{ab}$ & NS & $4.6 \mathrm{a}$ & $4.1 \mathrm{ab}$ & * & $10 \mathrm{ab}$ & $12 \mathrm{ab}$ & * \\
\hline Peat-perlite control & $13.8 \mathrm{~b}$ & $14.0 \mathrm{ab}$ & NS & $3.8 \mathrm{ab}$ & $3.0 \mathrm{~cd}$ & NS & $4.5 \mathrm{a}$ & $4.0 \mathrm{~b}$ & * & $8 \mathrm{~b}$ & $9 \mathrm{c}$ & * \\
\hline Biosolids blend control & $14.1 \mathrm{ab}$ & $13.7 \mathrm{ab}$ & NS & $3.6 \mathrm{~b}$ & $3.3 \mathrm{bcd}$ & NS & $4.5 \mathrm{a}$ & $4.0 \mathrm{~b}$ & * & $12 \mathrm{a}$ & $13 \mathrm{a}$ & NS \\
\hline \multicolumn{13}{|c|}{ Pepper } \\
\hline Construction debris-biosolids:bark & $27.3 \mathrm{a}$ & $23.9 \mathrm{ab}$ & ** & $6.7 \mathrm{a}$ & $4.5 \mathrm{a}$ & $* * *$ & $5.0 \mathrm{a}$ & $4.0 \mathrm{a}$ & *** & $19 \mathrm{a}$ & $13 \mathrm{ab}$ & ** \\
\hline Horse waste-biosolids:bark & $27.4 \mathrm{a}$ & $23.5 \mathrm{~b}$ & $* * *$ & $7.2 \mathrm{a}$ & $4.1 \mathrm{ab}$ & $* * *$ & $5.0 \mathrm{a}$ & $4.0 \mathrm{a}$ & $* * *$ & $21 \mathrm{a}$ & $11 \mathrm{ab}$ & *** \\
\hline Peat-perlite control & $27.8 \mathrm{a}$ & $25.9 \mathrm{a}$ & * * & $7.6 \mathrm{a}$ & $4.9 \mathrm{a}$ & $* * *$ & $5.0 \mathrm{a}^{\mathrm{y}}$ & $4.0 \mathrm{a}$ & $* * *$ & $20 \mathrm{a}$ & $15 \mathrm{a}$ & ** \\
\hline Biosolids blend control & $27.2 \mathrm{a}$ & $23.0 \mathrm{~b}$ & $* * *$ & $6.6 \mathrm{a}$ & $4.1 \mathrm{ab}$ & $* * *$ & $4.8 \mathrm{a}$ & $4.0 \mathrm{a}$ & $* *$ & $19 \mathrm{a}$ & $13 \mathrm{ab}$ & * \\
\hline
\end{tabular}

${ }^{\mathrm{z}}$ Shoot growth index $=\{[$ (widest width + narrowest width $) \div 2]+$ height $\} \div 2 ; 1 \mathrm{~cm}=0.3937$ inch .

${ }^{\mathrm{y}} \mathrm{l} \mathrm{g}=0.0353 \mathrm{oz}$.

$\times 5=$ superior, $1=$ poor, and a rating of 3 was considered marketable.

"High $\mathrm{N}$ plants fertilized with $200 \mathrm{mg} \cdot \mathrm{L}^{-1} \mathrm{~N}$ every other day; Low $\mathrm{N}$ plants fertilized with $200 \mathrm{mg} \cdot \mathrm{L}^{-1} \mathrm{~N}$ every $4 \mathrm{~d} ; \mathrm{l} \mathrm{mg} \cdot \mathrm{L}^{-1}=1 \mathrm{ppm}$.

"Means within a column and species followed by the same letter are not significantly different at the $5 \%$ level using a protected Tukey's Studentized range test.

${ }^{\mathrm{u}} \mathrm{NS},{ }^{*},{ }^{* *}$, and ${ }^{* * *}$ are used to indicate nonsignificance and significance at the $5 \%, 1 \%$ and $0.1 \%$ level, respectively, as determined by Student's $t$ test of the fertilizer effect within a treatment. 
increased at the high $\mathrm{N}$ rate. However, visual quality of marigold in the low $\mathrm{N}$ rate treatment was reduced in all but the construction debrisbiosolids and horse waste-biosolids substrates (Table 3). Nitrogen rate did not influence the number of flowers or visible buds on marigold in the construction debris-biosolids, horse waste-biosolids, digester solids, or biosolids blend control substrates. More marigold flowers and buds were visible at the high $\mathrm{N}$ rate in commercial biosolids compost and fewer in the storm debris-biosolids and peatperlite substrates.

Pepper plants exhibited a consistent positive response to $\mathrm{N}$ rate with SGI, dry weight, visual quality rating, and flower and bud numbers in all substrates enhanced by $\mathrm{N}$ fertilization at the high rate (Table 3 ). The positive growth response of pepper to increased $\mathrm{N}$ in all seven substrates contrasts with marigold, where $\mathrm{N}$ rate had no effect on SGI in five and dry weight in six of the seven substrates (Table 3 ). The production time for pepper in this experiment was 11 weeks from seed to first open flower, while marigold required only 7 weeks to reach first flower. The longer growth period and typically greater biomass of the pepper in this experiment resulted in a higher $\mathrm{N}$ demand and plants that consistently benefitted from the additional N. Sterrett (2001) indicated that vegetable transplant production for commercial vegetable growers differs from transplants for the retail market. The intent of this research was pepper transplant production for the retail market.

Hummel et al. (2000) found that increased $\mathrm{N}$ application did not influence SGI, dry weight, and quality of 'Queen Sophia' marigold grown in $100 \%$ fish waste compost at 7 weeks after transplant, but the quality and SGI of 'Sprinter Scarlet' geranium (Pelargonium $\times$ hortorum) which took 9 weeks to finish, was enhanced by the addition of N. Chaney et al. (1980) reported that $33 \%$ composted sewage sludge supplied part of the $\mathrm{N}$ for 'Double Eagle' marigold in a peat:vermiculite mix and that high soluble salts in the $67 \%$ and $100 \%$ sewage sludge compost substrates obscured any potential $\mathrm{N}$ influence on plant growth. Falahi-Ardakani et al. (1987a) grew vegetable transplants in market packs using a substrate of equal parts by volume sewage sludge compost, peatmoss, and perlite and found that broccoli (Brassica oleracea Italica Group) and cabbage (B. oleracea Capitata Group) could be grown to transplant size without added fertilizer, but 'Yolo' pepper plants required some additional N. In a second study (Falahi-Ardakani et al., 1987b), they determined the initial fertilizer application could be delayed 1 to 2 weeks after transplant and a constant or biweekly fertilization schedule was unnecessary.

Results of root growth ratings indicated $\mathrm{N}$ rate did not influence root growth of marigold or pepper plants in this experiment (data not shown). Root length as determined by rating the length of roots visible at the periphery of the root ball was unaffected by $\mathrm{N}$ rate. Roots of plants in all treatments grew to circle the container bottoms, and root density at the periphery of the root ball was substantial with many roots visible but the container substrate was still obvious. Root density ratings of 'Queen Sophia' marigold in 100\% fish waste compost and $50 \%$ fish waste compost: $50 \%$ douglas fir bark substrates were unaffected by increasing $\mathrm{N}$ rates from 0 to $600 \mathrm{ppm}$ every 2 weeks (Hummel et al., 2000). In their experiment, doubling the amount of $\mathrm{N}$ from 300 to $600 \mathrm{ppm}$ applied to plants in the $100 \%$ bark substrate did not change root density but plants receiving no $\mathrm{N}$ had fewer roots visible at the root ball periphery.

Container substrates. Marigold grown at the high $\mathrm{N}$ rate in the construction debris-biosolids substrate had a significantly greater SGI than the peat-perlite control plants, but all other substrates produced plants with similar SGI to the controls (Table 3). Under low $\mathrm{N}$, the commercial biosolids compost substrate had lower SGI than the peat-perlite and biosolids blend controls, while all other substrates produced plants similar to the controls. All substrate treatments were similar to the peatperlite control for marigold dry weight under the high $\mathrm{N}$ regime, but horse waste-biosolids plants were larger than the biosolids blend controls. Dry weight of marigold in the low $\mathrm{N}$ treatment was similar to the peat-perlite and biosolids blend controls in all substrates except horse waste-biosolids where plants were larger. Growth of marigold in the horse waste-biosolids substrate indicates the initial EC of $1.6 \mathrm{dS} \cdot \mathrm{m}^{-1}$ (Table 2) was not injurious to plants in this experiment.

Visual quality ratings of marigold at the high $\mathrm{N}$ rate were similar across all substrates except for lower ratings of plants in commercial biosolids compost (Table 3 ). At the low $\mathrm{N}$ rate, marigold grown in commercial biosolids compost and digester solids were of lower quality than the controls, while plants in the horse wastebiosolids were of higher quality. All marigold had one fully open flower but plants in the peat-perlite substrate had fewer flowers and visible buds than plants in all but the storm debris-biosolids substrate at the high $\mathrm{N}$ rate. At the low $\mathrm{N}$ rate, marigold in the horse waste-biosolids, biosolids blend control, and storm debris-biosolids substrates had more flowers and buds than those grown in the peat-perlite mix.

Pepper plants in all substrates except commercial biosolids compost had similar SGIs at the high $\mathrm{N}$ rate (Table 3 ). Shoot growth index and dry weight of pepper in commercial biosolids compost and dry weight of pepper in digester solids were lower than for plants grown in the other substrates at the high $\mathrm{N}$ rate. At the low $\mathrm{N}$ rate, pepper in commercial biosolids compost also had the smallest SGI and dry weights. Dry weights of low $\mathrm{N}$ fertilizer pepper grown in the three experimental biosolids compost:bark substrates were similar to the peat-perlite and biosolids blend controls, but SGI in horse wastebiosolids and biosolids blend control was smaller than in peat-perlite. Low $\mathrm{N}$ digester solids-grown pepper were smaller than peat-perlite plants but similar to biosolids blend controls.

At the high $\mathrm{N}$ rate, plant quality as well as flower and visible bud numbers of pepper plants grown in the three experimental biosolids compost-bark substrates was similar to the peat-perlite and the biosolids blend controls, whereas quality, flower, and bud numbers of commercial biosolids compost and quality of digester solids grown pepper was inferior to plants in the other substrates (Table 3 ). Results were similar at the low $\mathrm{N}$ rate with commercial biosolids compost and digester solids scoring lower visual ratings than the other substrates and 
commercial biosolids compost-grown pepper averaging only four flowers and visible buds. Low $\mathrm{N}$ fertilized pepper in digester solids produced fewer flowers and buds than the peat-perlite controls (Table 3 ).

Both pepper and marigold visual quality ratings indicated plants in all treatments were marketable (Table 3 ). However, at the low $\mathrm{N}$ rate, commercial biosolids compost plants barely achieved marketable quality. When the four measured parameters (SGI, dry weight, quality, and flower/ bud number) at both $\mathrm{N}$ rates were compared with the peat-perlite control, marigold and pepper performance was inferior in the commercial biosolids compost and digester solids substrates (Table 3). Inferior plant growth in these substrates may be attributable to the high $\mathrm{C}: \mathrm{N}$ ratio (29:1) and lower $\mathrm{NO}_{3}-\mathrm{N}$ level (17 $\left.\mathrm{mg} \cdot \mathrm{L}^{-1}\right)$ of commercial biosolids compost and the higher initial $\mathrm{pH}$ (6.8) and lower $\mathrm{NO}_{3}-\mathrm{N}$ level (2l $\left.\mathrm{mg} \cdot \mathrm{L}^{-1}\right)$ of the digester solids. Marigold and pepper plants in the three substrates composed of biosolids composted in bins with either horse waste, construction, or storm debris typically had measured parameters equal or superior to the peat-perlite controls. Klock-Moore (1999) found substrates containing biosolids and yard trimmings compost produced significantly larger begonia (Begonia $\times$ semperflorens-cultorum and impatiens (Impatiens wallerana) plants than substrates made from recycled greenhouse substrates and yard trimmings. The increased growth was attributed to the higher initial nutrient concentrations in substrates containing biosolids.

Root length and density ratings of both marigold and pepper plants in the experimental substrates were similar to ratings of plants in the control substrates (data not shown). Roots of plants in all substrates grew to circle the container bottoms and root growth at the periphery of the root ball was substantial, but container substrates were readily visible. Li et al. (2009) compared root growth of sprenger asparagus (Asparagus densiflorus) seedlings grown in a $20 \%$ perlite:20\% vermiculite:60\% Canadian sphagnum peat substrate to seedlings grown in six substrates where the peat was replaced by composted cow manure at $10 \%$ increments up to $60 \%$. They found similar root dry weights in all seven substrates.

\section{Leaf color}

Leaf color is a component of plant visual quality and plant health that can be measured objectively and compared statistically using a tristimulus colorimeter (McGuire 1992). Although the perceived relationship between leaf color and plant quality is subject to personal preference and varies with plant species, cultivar, or both, for most plants, high quality and good health are typically associated with dark green leaves. The high $\mathrm{N}$ treatment resulted in marigold with significantly darker (lower L*) and greener (greater hue angle) leaves with a lower chroma when compared with the low $\mathrm{N}$ treatment in all but two of 21 possible comparisons (Table 4 ). In construction debris-biosolids and

Table 4. Effect of growth substrates and nitrogen $(\mathrm{N})$ rates on leaf color characteristics of lightness $\left(\mathrm{L}^{*}\right)$, chroma and hue angle of 'Little Hero Flame' marigold and 'Golden California Wonder' pepper. Construction debris-biosolids, horse wastebiosolids, and storm debris-biosolids composts were made in small-scale aerobic reactors and the digester solids and commercial biosolids compost were obtained from local manufacturers. Bark indicates substrates were amended with douglas fir bark at a 1:1 (v:v) ratio. Peat-perlite and biosolids blend are commercially available growth substrates and were used as controls.

\begin{tabular}{|c|c|c|c|c|c|c|c|c|c|}
\hline \multirow[b]{2}{*}{ Substrates } & \multicolumn{3}{|c|}{$L^{* z}$} & \multicolumn{3}{|c|}{ Chroma $^{y}$} & \multicolumn{3}{|c|}{ Hue angle ${ }^{\mathrm{x}}$} \\
\hline & High N $^{w}$ & Low $\mathbf{N}^{w}$ & & High $\mathbf{N}$ & Low $\mathbf{N}$ & & High N & Low & \\
\hline \multicolumn{10}{|c|}{ Marigold } \\
\hline Construction debris-biosolids:bark & $37.2 \mathrm{ab}^{\mathrm{v}}$ & $38.5 \mathrm{c}$ & $\mathrm{NS}^{\mathrm{u}}$ & $15.6 \mathrm{~b}$ & $17.7 \mathrm{c}$ & $* * *$ & $134.9 \mathrm{a}$ & $133.1 \mathrm{a}$ & * \\
\hline Horse waste-biosolids:bark & $37.0 \mathrm{ab}$ & $38.1 \mathrm{c}$ & $* *$ & $14.6 \mathrm{~b}$ & $16.9 \mathrm{c}$ & $* * *$ & $135.3 \mathrm{a}$ & $133.7 \mathrm{a}$ & ** \\
\hline Storm debris-biosolids:bark & $36.6 \mathrm{~b}$ & $38.3 \mathrm{c}$ & $* * *$ & $14.5 \mathrm{~b}$ & $17.4 \mathrm{c}$ & $* * *$ & $135.6 \mathrm{a}$ & $132.7 \mathrm{ab}$ & $* * *$ \\
\hline Digester solids:bark & $37.1 \mathrm{ab}$ & $40.3 \mathrm{~b}$ & $* * *$ & $15.7 \mathrm{~b}$ & $21.0 \mathrm{ab}$ & $* * *$ & $134.7 \mathrm{a}$ & $130.5 \mathrm{c}$ & $* * *$ \\
\hline Commercial biosolids compost:bark & $38.6 \mathrm{a}$ & $42.1 \mathrm{a}$ & $* * *$ & $19.1 \mathrm{a}$ & $22.8 \mathrm{a}$ & $* * *$ & $132.1 \mathrm{~b}$ & $128.4 \mathrm{~d}$ & $* * *$ \\
\hline Peat-perlite control & $36.2 \mathrm{~b}$ & $38.0 \mathrm{c}$ & $* * *$ & $14.1 \mathrm{~b}$ & $16.3 \mathrm{c}$ & NS & $135.6 \mathrm{a}$ & $133.6 \mathrm{a}$ & $* * *$ \\
\hline Biosolids blend control & $37.6 \mathrm{ab}$ & $39.1 \mathrm{bc}$ & ** & $16.1 \mathrm{~b}$ & $20.0 \mathrm{~b}$ & *** & $133.8 \mathrm{ab}$ & $131.2 \mathrm{bc}$ & $* * *$ \\
\hline \multicolumn{10}{|c|}{ Pepper } \\
\hline Construction debris-biosolids:bark & $46.1 \mathrm{c}$ & $48.9 \mathrm{~cd}$ & $* * *$ & $30.9 \mathrm{bcd}$ & $35.0 \mathrm{c}$ & $* * *$ & $124.2 \mathrm{a}$ & $122.0 \mathrm{ab}$ & ** \\
\hline Horse waste-biosolids:bark & $47.2 \mathrm{abc}$ & $50.1 \mathrm{bc}$ & $* * *$ & $33.0 \mathrm{abc}$ & $36.4 \mathrm{bc}$ & *** & $123.0 \mathrm{ab}$ & $120.6 \mathrm{bc}$ & $* * *$ \\
\hline Storm debris-biosolids:bark & $46.1 \mathrm{c}$ & $48.2 \mathrm{~d}$ & $* *$ & $30.8 \mathrm{~cd}$ & $34.4 \mathrm{c}$ & $* * *$ & $124.3 \mathrm{a}$ & $122.2 \mathrm{a}$ & $* * *$ \\
\hline Digester solids:bark & $47.7 \mathrm{abc}$ & $51.9 \mathrm{a}$ & $* * *$ & $33.2 \mathrm{ab}$ & 38.8 a & $* * *$ & $122.8 \mathrm{ab}$ & $119.3 \mathrm{~cd}$ & $* * *$ \\
\hline Commercial biosolids compost:bark & $48.2 \mathrm{a}$ & $52.8 \mathrm{a}$ & $* * *$ & $34.0 \mathrm{a}$ & $39.0 \mathrm{a}$ & *** & $122.1 \mathrm{~b}$ & $119.0 \mathrm{~d}$ & $* * *$ \\
\hline Peat-perlite control & $46.4 \mathrm{bc}$ & $51.3 \mathrm{ab}$ & $* * *$ & $30.0 \mathrm{~d}$ & $37.1 \mathrm{ab}$ & *** & $124.3 \mathrm{a}$ & $120.1 \mathrm{~cd}$ & $* * *$ \\
\hline Biosolids blend control & $48.1 \mathrm{ab}$ & $52.4 \mathrm{a}$ & $* * *$ & $34.1 \mathrm{a}$ & $38.5 \mathrm{ab}$ & $* * *$ & $122.3 \mathrm{~b}$ & $119.8 \mathrm{~cd}$ & $* * *$ \\
\hline
\end{tabular}

${ }^{\mathrm{z}} \mathrm{L}^{*}$ is the color lightness or value $0=$ black to $100=$ white.

y Chroma is the intensity of color from grey $(0)$ to pure chromatic color.

${ }^{\mathrm{x}}$ Hue Angle is the attribute of color perceived (red, yellow, green, blue or intermediate between adjacent pairs arranged on a $360^{\circ}$ color wheel, $0^{\circ}=$ red, $90^{\circ}=$ yellow, $180^{\circ}=$ green, and $270^{\circ}=$ blue).

"High $\mathrm{N}$ plants fertilized with $200 \mathrm{mg} \cdot \mathrm{L}^{-1} \mathrm{~N}$ every other day; Low $\mathrm{N}$ plants fertilized with $200 \mathrm{mg} \cdot \mathrm{L}^{-1} \mathrm{~N}$ every $4 \mathrm{~d} ; \mathrm{l} \mathrm{mg} \cdot \mathrm{L}^{-1}=1 \mathrm{ppm}$.

'Means within a column and species followed by the same letter are not significantly different at the $5 \%$ level using a protected Tukey's Studentized range test.

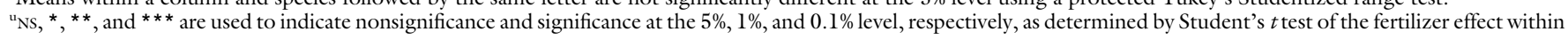
a treatment. 
the peat-perlite control, $\mathrm{N}$ rate had no effect on $L^{*}$ and chroma, respectively. In both the high and low $\mathrm{N}$ treatment, marigold grown in the experimental biosolids compost:bark substrates had similar leaf color to the controls, while marigold in the commercial biosolids compost substrate had less desirable color characteristics (Table 4). Marigold grown in the digester solids and the biosolids blend control substrates had similar color to peat-perlite under high $\mathrm{N}$ conditions, but inferior color with reduced $\mathrm{N}$. Rettke et al. (2006) used a Konica Minolta Chroma Meter and found apricot (Prunus armeniaca) leaves were significantly darker (lower $\mathrm{L}^{*}$ ), greener (greater hue angle) with less color saturation (lower chroma), as $\mathrm{N}$ application increased from 0 to 500 $\mathrm{g} /$ tree per year; at $\mathrm{N}$ higher rates, the trends continued but were not always significant.

Pepper leaf color characteristics in all growth substrates were improved by fertilization at the higher rate of $200 \mathrm{mg} \cdot \mathrm{L}^{-1} \mathrm{~N}$ every other day (Table 4). Pepper grown in the construction debris-biosolids compost and storm debris-biosolids compost substrates had superior leaf color $\left(\mathrm{L}^{*}\right.$, chroma, and hue angle) to the peatperlite control pepper under low $\mathrm{N}$ fertilization (Table 4). Leaf color parameters of low $\mathrm{N}$ plants in all other substrates were similar to the controls. Under high $\mathrm{N}$ fertilization, pepper grown in all three experimental biosolids compost substrates had similar color to peat-perlite except for horse waste-biosolids chroma. Leaf color of pepper in commercial biosolids compost was inferior to the peat-perlite control for all three measured parameters, but similar to the biosolids blend control.

The darker, greener leaves of pepper at low $\mathrm{N}$ levels for storm debris-biosolids and construction debris-biosolids substrates suggest a slow release of nitrogen from these materials led to measurable improvement in the quality of the pepper plants. Leaf color differences in Nfertilized bentgrass (Agrostis stolonifera) were detectable with a tristimulus colorimeter; $\mathrm{L}^{*}$ decreased, hue angle increased, and chroma showed no consistent response to increasing $\mathrm{N}$ rates (Landschoot and Mancino, 1997). The authors found both hue angle and $\mathrm{L}^{*}$ were correlated with foliar $\mathrm{N}$ concentrations and concluded that the colorimeter could, with "reasonable accuracy," predict foliar $\mathrm{N}$ concentrations.

According to Fitzpatrick (2001), relatively few studies have evaluated how compost feedstock composition changes influence the compost product quality. The studies that have been conducted indicated factors such as feedstocks and processing can cause major changes in the compost product's ability to serve as a substrate for containerized plant production. These changes include $\mathrm{pH}$, soluble salts, nutrients, and potentially phytotoxic materials, as well as physical properties such as AP and WHC. In this research, we manufactured three container substrates by cocomposting biosolids with three locally sourced urban waste feedstocks: horse waste, construction debris, or storm debris. After mixing the composts with bark, we found the APs or $\mathrm{pHs}$ of the resulting substrates were similar $(\mathrm{Ta}$ ble 2). Although statistically significant, the differences in WHC, EC, and $\mathrm{NO}_{3}-\mathrm{N}$ were relatively small. Not surprisingly, marigold and pepper growth, quality, and leaf color characteristics were similar in the three substrates.

\section{Conclusions}

Based on the results from marigold and pepper, the experimental biosolids compost growth substrates produced from composts made in the small-scale aerobic bins have similar to slightly better performance overall to the peat-perlite and biosolids blend controls, while the digester solids mix and particularly the commercial biosolids compost mix lagged behind the others. This was despite the coarseness of the alternative container substrates compared with peatperlite and biosolids blend controls, resulting in higher $\mathrm{AP}$ and lower WHC. The three experimental biosolids composts had relatively low C:N ratios (14:1 to $16: 1$ ) and high initial nitrate levels (Table 2), indicating their capability to provide supplemental $\mathrm{N}$ to the plants. When mixed with bark, they also had $\mathrm{pH}$ levels similar to the control substrates. The biosolids blend control also contained biosolids, but these were more highly processed and biologically stable materials, likely with a lower rate of $\mathrm{N}$ release, leading to less plant growth. The commercial biosolids compost substrate likely had the lowest rate of $\mathrm{N}$ release, or even $\mathrm{N}$ immobilization, based on the high C:N ratio of the feedstock (29:1). The poorer plant performance in the digester solids may have been related to the initially higher $\mathrm{pH}$ and lower available $\mathrm{N}$ of the substrate.

The drip irrigation regime with emitters encircling the plant may have compensated for the reduced WHC of the experimental substrates. Although plants grew well under the conditions of this study, they may not grow as well under different irrigation systems or management. This suggests that additional work could be done to improve the quality and consistency of the substrates, perhaps by custom grinding or screening of the woody feedstocks.

\section{Literature cited}

Bettineski, L. 1996. How nurseries can benefit from composting. The Digger 40(4):19-23.

Bugbee, G.J. 2002. Growth of ornamental plants in container media amended with biosolids compost. Compost Sci. Util. 10:92-98.

Carlile, W.R. 2008. The use of composted materials in growing media. Acta Hort. 779:321-327.

Chaney, R.L., J.B. Munns, and H.M. Cathey. 1980. Effectiveness of digested sewage sludge compost in supplying nutrients for soilless potting media. J. Amer. Soc. Hort. Sci. 105:485-492.

City of Tacoma. 2011. Tagro potting soil. 6 Jan. 2014. <http://www.cityoftacoma.org/government/city_departments/ environmentalservices/tagro/tagro_home_users $/>$.

Clark, S. and M. Cavigelli. 2005. Suitability of composts as potting media for production of organic vegetable transplants. Compost Sci. Util. 13:150-156.

Estévez-Schwarz, I., S. Seoane, A. Núñez, and M.E. López-Mosquera. 2009. Characterization and evaluation of compost utilized as ornamental plant substrate. Compost Sci. Util. 17:210-219.

Falahi-Ardakani, A., J.C. Bouwkamp, F.R. Gouin, and R.L. Chaney. 1987a. Growth response and mineral uptake of vegetable transplants grown in a composted sewage sludge amended medium. I. Nutrient supplying power of the medium. J. Environ. Hort. 5:107-111. 
Falahi-Ardakani, A., F.R. Gouin, J.C. Bouwkamp, and R.L. Chaney. 1987b. Growth response and mineral uptake of vegetable transplants grown in a composted sewage sludge amended medium. II. Influenced by time of application of $\mathrm{N}$ and K. J. Environ. Hort. 5:112-115.

Fitzpatrick, G.E. 2001. Compost utilization in ornamental and nursery crop production systems, p. 135-150. In: P.J. Stoffella and B.A. Kahn (eds.). Compost utilization in horticultural cropping systems. Lewis, Boca Raton, FL.

Frear, C., B. Zhao, G. Fu, M. Richardson, and S. Chen. 2005. Biomass inventory and bioenergy assessment: An evaluation of organic material resources for bioenergy production in Washington State. Washington Dept. Ecol. Document No. 05-07-047. 6 Jan. 2014. <http://www.ecy.wa.gov/ biblio/0507047.html>.

Gouin, F. 1995. Compost use in the horticultural industries. Green industry composting. BioCycle special report. JG Press, Emmaus, PA.

Hummel, R.L., S. Kuo, D. Winters, and E.J. Jellum. 2000. Fishwaste compost medium improves growth and quality of container-grown marigolds and geraniums without leaching. J. Environ. Hort. 18:93-98.

Ingram, D.L., R.W. Henley, and T.H. Yeager. 1990. Diagnostic and monitoring procedures for nursery crops. Univ. Florida Coop. Ext. Circ. 556.

Jackson, B.E., R.D. Wright, and M.C. Barnes. 2010. Methods of constructing a pine tree substrate from various wood particle sizes, organic amendments, and sand for desired physical properties and plant growth. HortScience 45:103-112.

Klock-Moore, K.A. 1999. Bedding plant growth in greenhouse waste and biosolid compost. Hort Technology 9:210-213.

Krucker, M., R.L. Hummel, and C. Cogger. 2010. Chrysanthemum production in composted and noncomposted organic waste substrates fertilized with nitrogen at two rates using surface and subirrigation. HortScience 45:16951701 .

Landschoot, P.J. and C.F. Mancino. 1997. Assessment of the Minolta CR310 chroma meter for predicting nitrogen status of Agrostis stolonifera L. Intl. Turfgrass Soc. Res. J. 8:711-718.

Li, Q., J. Chen, R.D. Caldwekk, and M. Deng. 2009. Cowpeat as a substitute for peat in container substrates for foliage plant propagation. HortTechnology 19:340-345.

McGuire, R.G. 1992. Reporting of objective color measurements. HortScience 27:1254-1255

Moore, K.K. 2005. Uses of compost in potting mixes. HortTechnology 15:5860.

Nelson, P.V. 2012. Greenhouse operation and management. 7th ed. Pearson Prentice Hall, Upper Saddle River, NJ.

Raviv, M. 1998. Horticultural uses of composted material. Acta Hort. 469:225234.

Raviv, M. 2005. Production of highquality composts for horticultural purposes: A mini-review. HortTechnology 15:52-57.
Rettke, M.A., T.R. Pitt, N.A. Maier, and J.A. Jones. 2006. Growth and yield responses of apricot (cv. Moorpark) to soilapplied nitrogen. Austral. J. Exp. Agr. 46:115-122

Sterrett, S.B. 2001. Composts as horticultural substrates for vegetable transplant production, p. 227-240. In: P.J. Stoffella and B.A. Kahn (eds.). Compost utilization in horticultural cropping systems. Lewis, Boca Raton, FL.

Sullivan, D.M., C.G. Cogger, and A.I. Bary. 2007. Fertilizing with biosolids. Oregon State Univ. Ext. PNW 508e.

Thompson, W.H., P.B. Leege, P.D. Millner, and M.E. Watson. 2001. Test methods for the examination of composting and compost. U.S. Dept. Agr./ United States Composting Council Res. Educ. Foundation, Bethesda, MD.

Tyler, R.W. 1996. Winning the organics game. ASHS Press, Alexandria, VA.

U.S. Environmental Protection Agency. 1994. A plain English guide to the EPA Part 503 biosolids rule. EPA/832/R93/003. U.S. Environ. Protection Agency, Office Wastewater Mgt., Washington, DC.

Warncke, D.D. and D.M. Krauskopf. 1983. Greenhouse growth media: Testing and nutrition guidelines. Michigan State Univ. Ext. Bul. E-1736.

Yue, C., J.H. Dennis, B.K. Behe, C.R. Hall, B.L. Campbell, and R.G. Lopez. 2011. Investigating consumer preference for organic, local, or sustainable plants. HortScience 46:610-615. 